\title{
Fish community structure in San Agustín Bay, Huatulco, Mexico
}

\author{
Estructura comunitaria de peces en bahía San Agustín, Huatulco, México
}

\author{
MARTÍN RAMÍREZ-GUTIÉRREZ ${ }^{1 *}$, MARGARITO TAPIA-GARCÍA ${ }^{1 * *}$, \\ EDUARDO RAMOS-SANTIAGO² \& RAÚL ULLOA ${ }^{3}$
}

\author{
${ }^{1}$ Departamento de Hidrobiología, Universidad Autónoma Metropolitana-Iztapalapa, México, Distrito Federal, \\ Casilla Postal 55535,09340; e-mail: *jomaragu@hotmail.com; **mtg@xanum.uam.mx \\ ${ }^{2}$ Dirección General de Investigación del Pacífico Sur, Instituto Nacional de la Pesca, Playa Abierta s/n, Col. Miramar, \\ Salina Cruz, Oaxaca, México, Casilla Postal 70680; \\ e-mail: edurasa@hotmail.com \\ ${ }^{3}$ Comunidad y Biodiversidad, A.C., Boulevard Agua Marina 297, Col. Delicias, Guaymas, Sonora, México, \\ Casilla Postal 85420; e-mail: rulloa@ cobi.org.mx
}

\begin{abstract}
San Agustín bay is one of the most important bays in the Huatulco National Park because it includes the broadest coral reef surface of this park, which supports a great diversity of fish species. The importance of the present work is that describes quantitatively, for first time, the fish assemblage of this reef area. Visual censuses were realized on transects, according to the coral reef size, on coral and rocky reefs, and coral rubble environments. 64 species, 46 genus and 29 families were registered. Seasonal variation in fish assemblage was observed; reflecting the influence of pelagic shoaling species associated with the Gulf of Tehuantepec upwelling, during the dry season. Thus species were Selar crumenophthalmus, Caranx caninus, and Sardinops caeruleus. For species more closely associated to the reef habitat little seasonal variation was observed for each species, except Chromis atrilobata, which exhibited high density during the dry season. Pomacentrids exhibited more affinity for coral reef, labrids and haemulids for coral rubble environments. The highest diversity values were on coral rubble and the highest density was on the coral reef. Our study suggests that in this region, the Gulf of Tehuantepec upwelling is an important factor as well as the heterogeneity of habitats in shaping the fish assemblages, which must be protected to maintain the biodiversity of this important ecosystem.
\end{abstract}

Key words: Huatulco National Park, coral reef, diversity, density, community.

\section{RESUMEN}

La bahía de San Agustín es una de las más importantes del Parque Nacional Huatulco debido a que incluye al arrecife coralino más grande de este parque, el cual alberga una gran diversidad de especies de peces. La importancia del presente trabajo es describir cuantitativamente, por primera vez, la comunidad de peces de este hábitat de arrecifes. Para ello se realizaron censos visuales en transectos de acuerdo al tamaño de los ambientes coralino, rocoso y de escombros. 64 especies, 46 géneros y 29 familias fueron registrados. Se observaron cambios estacionales en la comunidad de peces, reflejando la influencia de las especies pelágicas asociadas a la surgencia del golfo de Tehuantepec, durante la temporada de secas. Estas especies fueron Selar crumenophthalmus, Caranx caninus y Sardinops caeruleus. Para las especies más cercanamente asociadas al arrecife, pequeñas variaciones estacionales fueron observadas para cada una de las especies, a excepción de Chromis atrilobata, que mostró alta densidad en la temporada de secas. Los pomacentridos mostraron mayor afinidad por el arrecife coralino, los labridos y haemulidos por el ambiente de escombros de coral. La mayor diversidad se registró en el ambiente de escombros de coral y la mayor densidad en el arrecife coralino. Nuestro trabajo sugiere que en esta región, la surgencia del golfo de Tehuantepec es un importante factor al igual que la heterogeneidad de hábitats en la conformación de la comunidad de peces, la cual debe ser protegida para mantener la biodiversidad de este importante ecosistema.

Palabras clave: Parque Nacional Huatulco, arrecife coralino, diversidad, abundancia, comunidad. 


\section{INTRODUCTION}

In Mexico, the great coral reef extensions are in the coasts of Quintana Roo, with small reef areas in Veracruz, the Campeche Bank, the Gulf of California, Pacific islands, and the Huatulco Bays. With relation to the southern Mexican Pacific, in the Huatulco Bays, there are a great number of small coral reef patches, but very important in a biogeography point of view, because this ecosystem supports the richest coral reef formation (17 species) of the Mexican Pacific coast (Leyte-Morales 2001). One of these species is probably endemic, and several more unique in México (Reyes \& Leyte 1998).

As a result of the attractive natural landscape of the bays, and the biological an ecological importance of the tropical forest and the marine environments, it was created the National Park Huatulco which includes eleven bays with coral reef (Parque Nacional Huatulco 2000). The National Commission for the Biodiversity of Mexico named to the Huatulco bays as a marine priority region, and also the group of bays is a RAMSAR site. The bays are very important in an economic point of view, because there is a tourist complex managed by the government, named Bahías de Huatulco. One of the most important bays in the National Park Huatulco is San Agustin Bay, which has a broad coral reef surface, where the aquatic activities like the diving and the snorkeling are important, besides that, the navigation of boats is allowed outside the coral reef area. If the pollution generated by tourism on beaches is added to these activities, there are several impacts on the bay, mainly on the coral reef and associated biota, as the fish community. Furthermore there is only one job which treats about the fish community of this bay (Barrientos-Villalobos 2000). Therefore, it is necessary to have a better knowledge of the Huatulco bays and to generate information that allows understanding the impact of the tourist activities.

In coral reef ecosystems, the fish species have an important role on the energy balance, where the majorities are carnivorous, few species are plankton feeders, and several are coral feeders and herbivorous (Sorokin 1995, Lieske \& Myers 1998). About this, the main objective of this study is to know the fish species composition, diversity, distribution, density and seasonal variation to understand how the fish community is functioning. Also this information represents a base for future studies about the biological and ecological strategies of fish species and how they collaborate on the ecological balance of the system. The available results will be very important to apply adequately management strategies in the park.

\section{MATERIAL AND METHODS}

The San Agustín bay is one of the nine Huatulco bays, located in the southwestern Mexican Pacific coast (Fig. 1). The beach is approximately $1.500 \mathrm{~m}$ in length and its width varies from 20 to $80 \mathrm{~m}$, and the sand is fine and white. The coral reef measures $201 \mathrm{~m}$ wide and $131 \mathrm{~m}$ in length.

The visual censuses were in November 2002, March and April 2003, which correspond to dry season, and June, and August 2003 during the rain season. For visual censuses, two divers, according to Sale \& Douglas (1981), registered the observed species, the number of individuals by species, and general observations. Each transect consisted in units of $10 \mathrm{~m}$ length. The depth most of the time was lower than two meters. Thus, five (T2, T3, T6, T7, T8), three (T1, T5, T10) and two (T4 y T9) were allocated to the coral, coral rubble y rocky habitats, respectively (Fig. 1). Each transect position was registered with the aid of a GPS.

For the identification of fish species, it was a previous training for the visual censuses, considering the papers of Allen \& Robertson (1994), Fischer et al. (1995), and we also measured temperature $\left({ }^{\circ} \mathrm{C}\right), \mathrm{pH}$ and dissolved oxygen $(\mathrm{mg} / \mathrm{l})$. Salinity (psu) was taken from Sosa-Rosas (1995).

We made a systematic list of fish species according to Nelson (1994). We estimated density in individuals $\mathrm{m}^{-2}$. The Shannon and Wiener (H'), species richness (D'), and the equitability (J') index were used to analyze the fish assemblage (Shannon \& Wiener 1963, Margalef 1968, Pielou 1977). Also, for the affinity analysis and distribution patterns of fish groups, we used the classification analysis by conglomerates through the method of Ward (1963) considering the density of the species (Pielou 1984), through the statistical software Statistica for Windows (C) Stat Soft, Inc.). Finally, we applied a t-student test to compare 

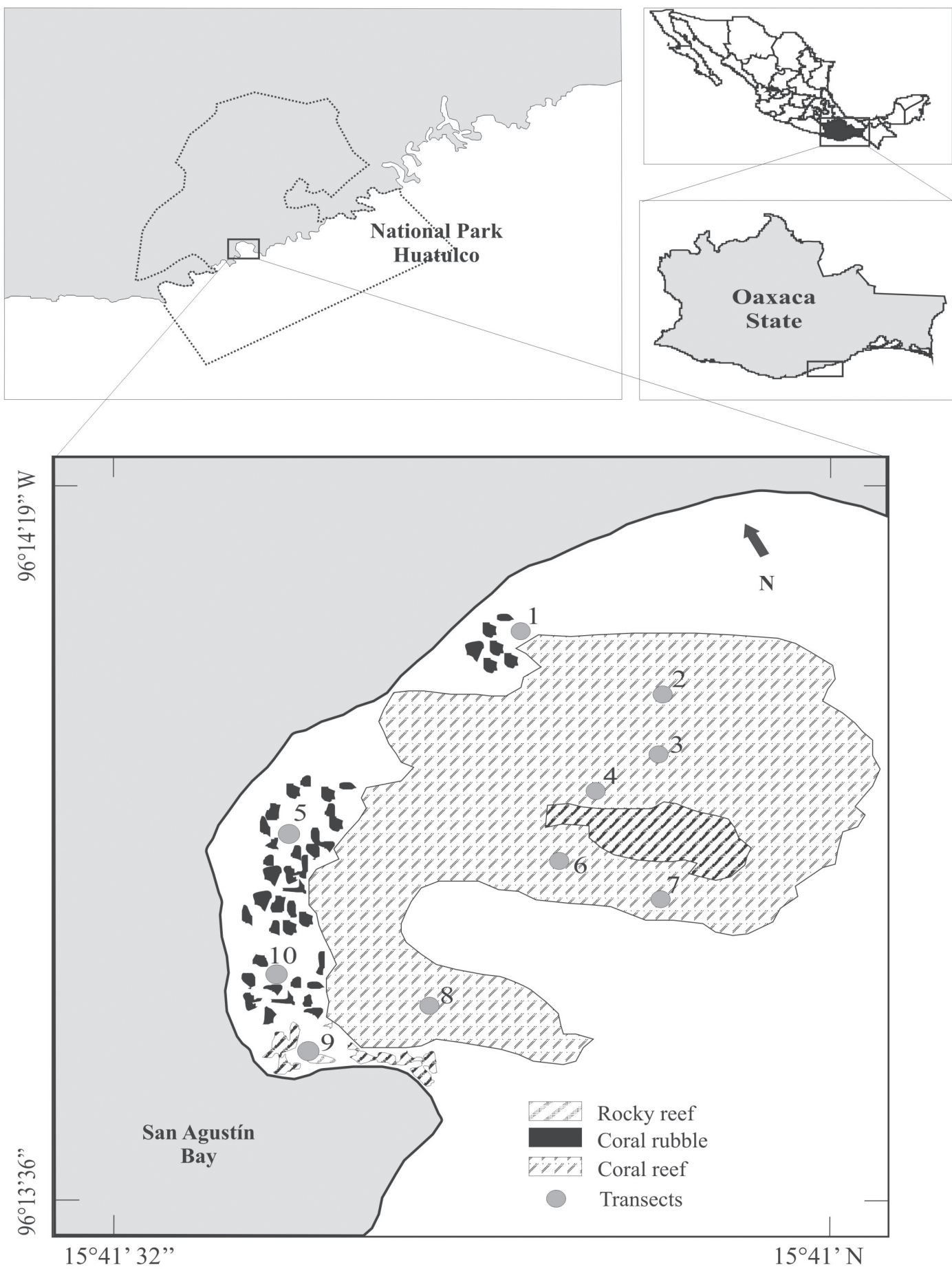

Fig. 1: Geographic location of transects in the study area.

Localización geográfica de los transectos en el área de estudio. 
the diversities of two samples using the Shannon-Wiener index, to determine if exist significant differences between the diversities of the different environments (Zar 1984).

Our primary goals of this study were; first, to describe the overall fish assemblage associated with reef habitat (coral, coral rubble and rock) within the bay, secondly to determine if reef fish assemblages differ among the reef habitats (coral, coral rubble and rock, and thirdly if and how the assemblages varied seasonally.

\section{RESULTS}

A total of 63 species, 46 genera and 29 families, was determined. The number of species by family is showed in the Table 1 . The highest number of individuals was registered in June and August, with 2.631 individuals (47 species and 25 families), and 2.156 individuals (37 species and 19 families) respectively. November presented the lowest density, with 369 individuals, 29 species and 15 families (Fig. 2A).

Seasonally the highest density was in June, and the lowest in November. With relation to the diversity, the highest values corresponded to April, June, and August, and the lowest in March. The highest density corresponded to the coral reef, and the lowest to coral rubble (Fig. $2 \mathrm{~A}$ and $3 \mathrm{~A})$. With relation to diversity the highest values were registered on coral rubble. And the lowest on coral reef area. By transect, in August was registered the highest diversity (3.9), and the lowest (0.68) in March, in the zone of coral reef, and coral rubble (Fig. 2B and $3 \mathrm{~B})$. The highest average value of the species richness index (D') was in June (2.11), and the lowest in March (1.32). The highest values by transect were registered in these same months, June and August, with values of 3.18 and 2.77 respectively, both values corresponded to the area of coral rubble, and the lowest in November (2.28) on the coral reef (Fig. 2C and 3C). With relation to equitability index ( $\mathrm{J}$ '), it was observed that November presented the highest average value (0.68), followed by April (0.67) and August (0.61). By transect, the highest values corresponded to April and November, with values of 0.94 on areas of coral rubble, and 0.93 on rocky reef area, and the lowest value was of 0.82 in August on coral reef area (Fig. 2D and 3D).

The highest temperature average was registered in November $\left(24.6{ }^{\circ} \mathrm{C}\right)$, and the lowest temperature average in March $\left(24.8{ }^{\circ} \mathrm{C}\right)$. The highest average value of dissolved oxygen was in November $\left(5.2 \mathrm{mg} \mathrm{L}^{-1}\right)$, and the lowest in April $\left(3.3 \mathrm{mg} \mathrm{L}^{-1}\right)$. With relation to $\mathrm{pH}$ the highest average value was in August (8.3), and the lowest in March (7.3). The highest salinity average was in April of 32.9 psu, and the lowest in August of 31.7 psu (Fig. 4)

The classification of transects according to the method of Ward, basically formed two main groups for the months of November, June, and August. One group corresponded to the zone of coral rubble, and the other group corresponded to the coral reef zone. The rocky reef zone was classified within the group conformed by coral reef. In March and April, there was not a clear classification with relation to the different environments, especially in April (Fig. 5).

The species that presented higher relative density were Chromis atrilobata (Gill, 1862), Prionurus punctatus (Gill, 1862), Stegastes acapulcoensis (Fowler, 1944), S. flavilatus (Gill, 1863), and Thalasoma lucasanum (Gill, 1862), Ch. atrilobata, $P$. punctatus, and $S$. flavilatus were abundant only on the coral reef, and S. acapulcoensis, and T. lucasanum were abundant in the three environments (Table 1).

Temporally, the species with the highest density (upper to $50 \%$ ) were, in order of density: T. lucasanum, S. acapulcoensis, P. punctatus, Microsphatodon dorsalis (Gill, 1862), and Ch. atrilobata (Fig. 6). The species with the highest frequency (upper to $50 \%$ ) were, in order of frequency: $S$. acapulcoensis, T. lucasanum, $S$. flavilatus, $M$. dorsalis, and P. punctatus. In some cases, the most abundant species were not always the most frequent, like Ch. atrilobata, whose density was higher but not thus their frequency. The opposite happened with Ophioblennius steindachneri, with a frequency upper to $50 \%$, but with a low density $(<5 \%)$ (Fig. 6).

The differences between diversities by environments, according to the Student t-test, showed significant differences between the coral reef and rocky reef enviroments for all months. The other enviroments, coral rubble versus coral reef and coral rubble versus rocky reef, did not showed significant differences in any month (Table 2). 


\section{TABLE 1}

Relative density (\%) of the species for different environments in San Agustín bay.

Abundancia relativa (\%) de las especies para los diferentes ambientes de bahía San Agustín

\begin{tabular}{|c|c|c|c|}
\hline \multirow[t]{2}{*}{ Species } & \multicolumn{3}{|c|}{ Enviroment } \\
\hline & Coral reef & Coral rubble & Rocky reef \\
\hline \multicolumn{4}{|l|}{ Familia Urolophidae } \\
\hline Urobatis concentricus (Osborne y Nichols, 1916) & 0.023 & 0.710 & - \\
\hline \multicolumn{4}{|l|}{ Familia Myliobatidae } \\
\hline Aetobatus narinari (Euphrasen, 1790) & 0.070 & 0.041 & 0.297 \\
\hline \multicolumn{4}{|l|}{ Familia Murainidae } \\
\hline Gymnothorax castaneus (Jordan y Gilbert, 1882) & 0.023 & - & - \\
\hline \multicolumn{4}{|l|}{ Familia Ophichthidae } \\
\hline Myrichthys tigrinus (Girard, 1859) & - & 0.041 & - \\
\hline \multicolumn{4}{|l|}{ Familia Clupeidae } \\
\hline Sardinops caeruleus (Girard, 1854) & - & - & - \\
\hline \multicolumn{4}{|l|}{ Familia Synodontidae } \\
\hline Synodus lacertinus (Gilbert 1890) & - & 0.041 & 0.238 \\
\hline Synodus schurae (Hildebrand, 1946) & - & 0.083 & - \\
\hline \multicolumn{4}{|l|}{ Familia Mugilidae } \\
\hline Mugil curema (Valenciennes, 1846) & 0.117 & 1.629 & 1.786 \\
\hline \multicolumn{4}{|l|}{ Familia Belonidae } \\
\hline Platybelone argalus (Osburn y Nichols, 1916) & - & - & 2.977 \\
\hline \multicolumn{4}{|l|}{ Familia Hemiramphidae } \\
\hline Hemiramphus saltator (Gilbert y Starks, 1904) & 1.176 & 1.880 & - \\
\hline \multicolumn{4}{|l|}{ Familia Holocentridae } \\
\hline Myiripristis leiognathus (Valenciennes, 1836) & 0.047 & - & 0.119 \\
\hline Sargocentron suborbitalis (Girard, 1864) & - & - & 0.178 \\
\hline \multicolumn{4}{|l|}{ Familia Fistularidae } \\
\hline Fistularia commersonni (Rüppell, 1835) & 0.282 & 0.250 & 0.238 \\
\hline \multicolumn{4}{|l|}{ Familia Serranidae } \\
\hline Epinephelus labriformis (Jenyns, 1843) & 0.164 & 0.125 & 0.059 \\
\hline Epinephelus panamensis (Steindachner, 1876) & 0.188 & 0.083 & 0.178 \\
\hline Familia Carangidae & & & - \\
\hline Caranx caninus (Günther, 1869) & - & - & - \\
\hline Elegatis bipinnulata (Quoy y Gaimard, 1825) & 0.141 & - & - \\
\hline Selar crumenophthalmus (Bloch, 1793) & - & - & - \\
\hline Seriola rivoliana (Valenciennes, 1833) & - & - & 0.059 \\
\hline Trachinotus rhodopus (Gill, 1863) & - & 0.417 & - \\
\hline \multicolumn{4}{|l|}{ Familia Lutjanidae } \\
\hline Lutjanus argentiventris (Peters, 1869) & 0.070 & 0.125 & 0.416 \\
\hline \multicolumn{4}{|l|}{ Familia Gerreidae } \\
\hline Eucinostomus currani (Yañez-Aracibia, 1978) & 0.470 & 0.250 & 2.977 \\
\hline Gerres cinereus (Walbaum, 1792) & - & - & 0.059 \\
\hline \multicolumn{4}{|l|}{ Familia Haemulidae } \\
\hline Haemulon maculicauda (Gill, 1863) & 3.977 & 1.295 & 0.119 \\
\hline Haemulon sexfasciatum (Gill, 1863) & 1.247 & 4.763 & 1.846 \\
\hline Haemulon steindachneri (Jordan y Gilbert, 1881) & - & 0.083 & 1.250 \\
\hline \multicolumn{4}{|l|}{ Familia Mullidae } \\
\hline Mullodichthys dentatus (Gill, 1863) & 0.070 & 0.083 & 1.012 \\
\hline \multicolumn{4}{|l|}{ Familia Chaetodontidae } \\
\hline Chaetodon humeralis (Günther,1860) & 0.800 & 0.793 & 0.655 \\
\hline
\end{tabular}


TABLE 1 (continuation)

\begin{tabular}{|c|c|c|c|}
\hline \multirow[t]{2}{*}{ Species } & \multicolumn{3}{|c|}{ Enviroment } \\
\hline & Coral reef & Coral rubble & Rocky reef \\
\hline Jhonrandalia nigrirostris (Gill, 1863) & 0.047 & - & 0.059 \\
\hline Familia Pomacanthidae & - & & \\
\hline Holocanthus passer (Valenciennes, 1846) & 0.094 & - & - \\
\hline Pomacanthus zonipectus (Gill, 1862) & - & 0.041 & - \\
\hline \multicolumn{4}{|l|}{ Familia Kyphosidae } \\
\hline Kyphosus analogus (Gill, 1863) & 0.353 & 0.167 & 0.238 \\
\hline Kyphosus elegans (Peters, 1869) & - & 0.125 & - \\
\hline \multicolumn{4}{|l|}{ Familia Cirrithidae } \\
\hline Cirrhitus rivulatus (Valenciennes, 1855) & 0.188 & 0.125 & 0.357 \\
\hline \multicolumn{4}{|l|}{ Familia Pomacentridae } \\
\hline Abudefduf concolor (Gill, 1863) & - & 0.041 & 0.655 \\
\hline Abudefduf troschelii (Gill, 1862) & 0.588 & 0.793 & - \\
\hline Chromis atrilobata (Gill, 1862) & 18.595 & 4.306 & 17.867 \\
\hline Microsphatodon bairdii (Gill, 1862) & 0.164 & 0.125 & 0.178 \\
\hline Microsphatodon dorsalis (Gill, 1862) & 2.329 & 1.170 & 4.050 \\
\hline Pomacentidae sp. & 0.023 & - & 0.119 \\
\hline Stegastes acapulcoensis (Fowler, 1944) & 13.956 & 10.948 & 12.388 \\
\hline Stegastes flavilatus (Gill, 1863) & 12.591 & 2.005 & 1.667 \\
\hline Stegastes rectifraenum (Gill, 1862) & 0.164 & 0.167 & 0.059 \\
\hline \multicolumn{4}{|l|}{ Familia Labridae } \\
\hline Bodianus diplotaenia (Gill, 1862) & 0.400 & 0.417 & 1.012 \\
\hline Halichoeres chierchiae (Caporiacco, 1947) & 0.047 & 2.841 & 2.918 \\
\hline Halichoeres dispilus (Günther,1864) & - & 1.504 & 0.893 \\
\hline Halichoeres nicholsi (Jordan y Gilbert, 1881) & 0.023 & 0.626 & 0.059 \\
\hline Halichoeres notospilus (Günther,1864) & 0.235 & 1.922 & 1.429 \\
\hline Novaculichthys taeniourus (Lacèpede, 1801) & - & 0.125 & - \\
\hline Thalassoma lucasanum (Gill, 1863) & 45.281 & 22.231 & 33.650 \\
\hline Thalassoma grammaticum (Gilbert, 1890) & - & 0.041 & - \\
\hline Xyrichtys pavo (Valenciennes, 1840) & - & 0.041 & - \\
\hline \multicolumn{4}{|l|}{ Familia Scaridae } \\
\hline Scarus compressus (Osburn y Nichols, 1916) & 0.070 & 1.002 & 0.059 \\
\hline Scarus ghobban (Forsskål, 1775) & - & 0.083 & - \\
\hline Scarus rubroviolaceus (Bleeker, 1847) & - & 0.041 & - \\
\hline \multicolumn{4}{|l|}{ Familia Blenniidae } \\
\hline Ophioblennius steindachneri (Jordan y Evermann, 1989) & 1.012 & 1.546 & 3.156 \\
\hline \multicolumn{4}{|l|}{ Familia Acanthuridae } \\
\hline Acanthurus xanthopterus (Valenciennes, 1835) & - & 0.041 & - \\
\hline Prionurus laticlavius (Valenciennes, 1846) & 0.094 & - & - \\
\hline Prionurus punctatus (Gill, 1862) & 16.924 & 6.142 & 2.203 \\
\hline \multicolumn{4}{|l|}{ Familia Balistidae } \\
\hline Sufflamen verres (Gilbert y Starks, 1904) & 0.094 & 0.292 & 0.297 \\
\hline \multicolumn{4}{|l|}{ Familia Tetradontidae } \\
\hline Arothron meleagris (Bloch y Schneider, 1801) & 2.424 & 0.417 & 1.072 \\
\hline Arothron hispidus (Lenneaus, 1758) & - & - & 0.059 \\
\hline Canthigaster punctatissima (Gunther, 1870) & 0.047 & - & 0.119 \\
\hline \multicolumn{4}{|l|}{ Familia Diodontidae } \\
\hline Diodon holocahnthus (Linneaus, 1758) & 0.094 & 2.799 & 0.297 \\
\hline Diodon hystrix (Linneaus, 1758) & 0.094 & - & 0.059 \\
\hline Total & 100 & 100 & 100 \\
\hline
\end{tabular}



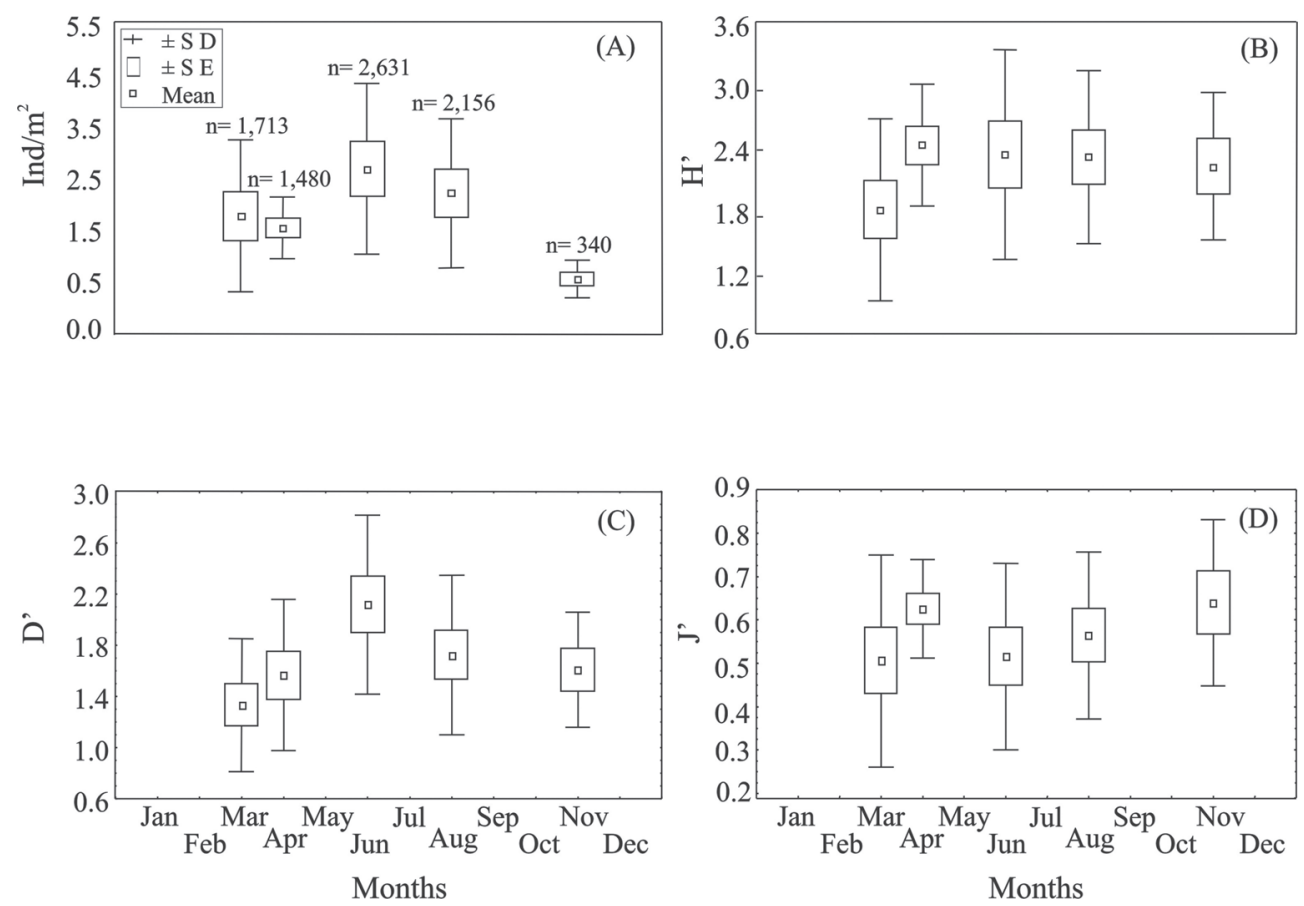

Fig. 2: Monthly variation of the community parameters: (A) density (individuals $\mathrm{m}^{-2}$ ), (B) diversity $\left(\mathrm{H}^{\prime}\right),(\mathrm{C})$ richness (D'), and (D) equitability (J').

Variación mensual de los parámetros comunitarios: (A) densidad (individuos $\mathrm{m}^{-2}$ ), (B) diversidad (H'), (C) riqueza (D') y (D) equidad ( ')
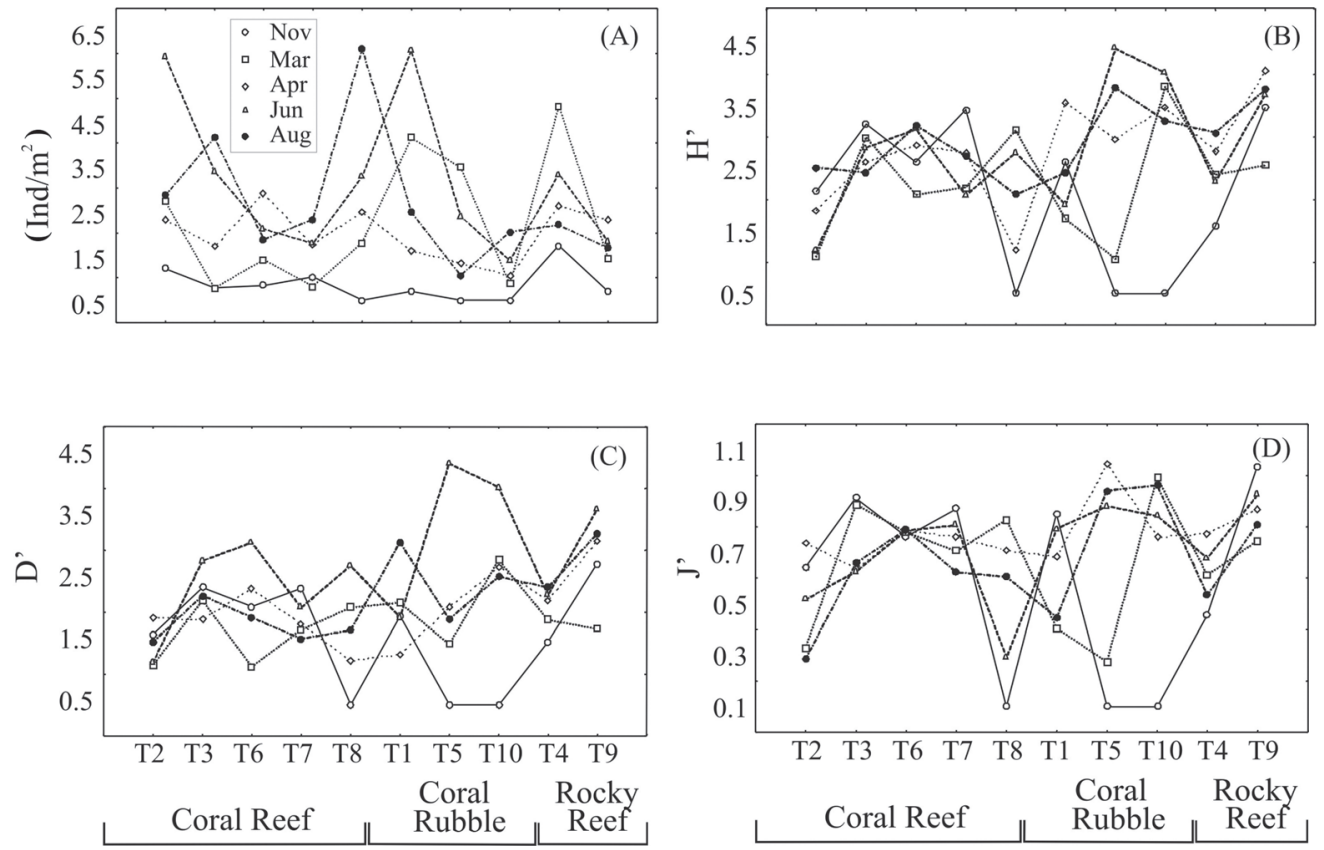

Fig. 3: Spatial variation of the community parameters by transects: (A) density (individuals $\mathrm{m}^{-2}$ ), (B) diversity (H'), (C) richness (D'), and (D) equitability (J').

Variación espacial de los parámetros comunitarios por transectos: (A) densidad (individuos $\mathrm{m}^{-2}$ ), (B) diversidad (H'), (C) riqueza (D') y (D) equidad (J'). 


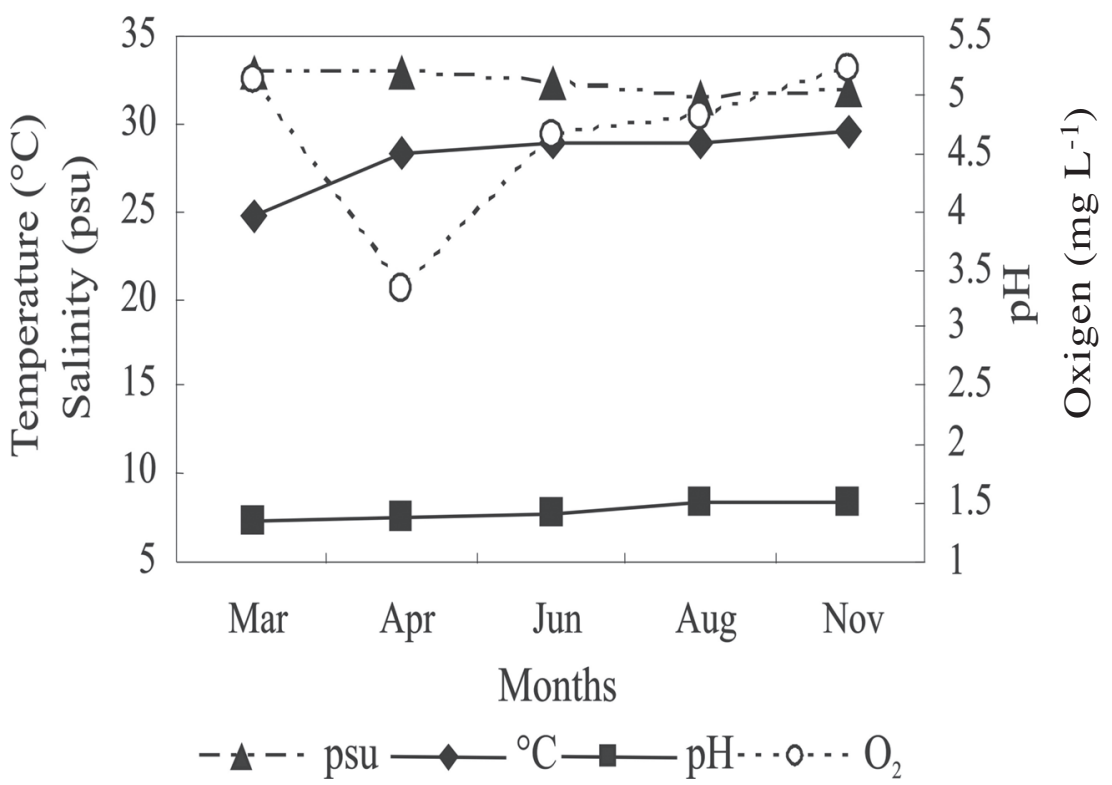

Fig. 4: Average variation of the oceanographic parameters: temperature $\left({ }^{\circ} \mathrm{C}\right), \mathrm{pH}$ and $\mathrm{O}_{2}\left(\mathrm{mg} \mathrm{L}^{-1}\right)$, salinity (psu) (Sosa-Rosas 1995).

Variación promedio de los parámetros oceanográficos: temperatura $\left({ }^{\circ} \mathrm{C}\right), \mathrm{pH}$ y $\mathrm{O}_{2}\left(\mathrm{mg} \mathrm{L}^{-1}\right)$, salinidad (psu) (Sosa-Rosas 1995).
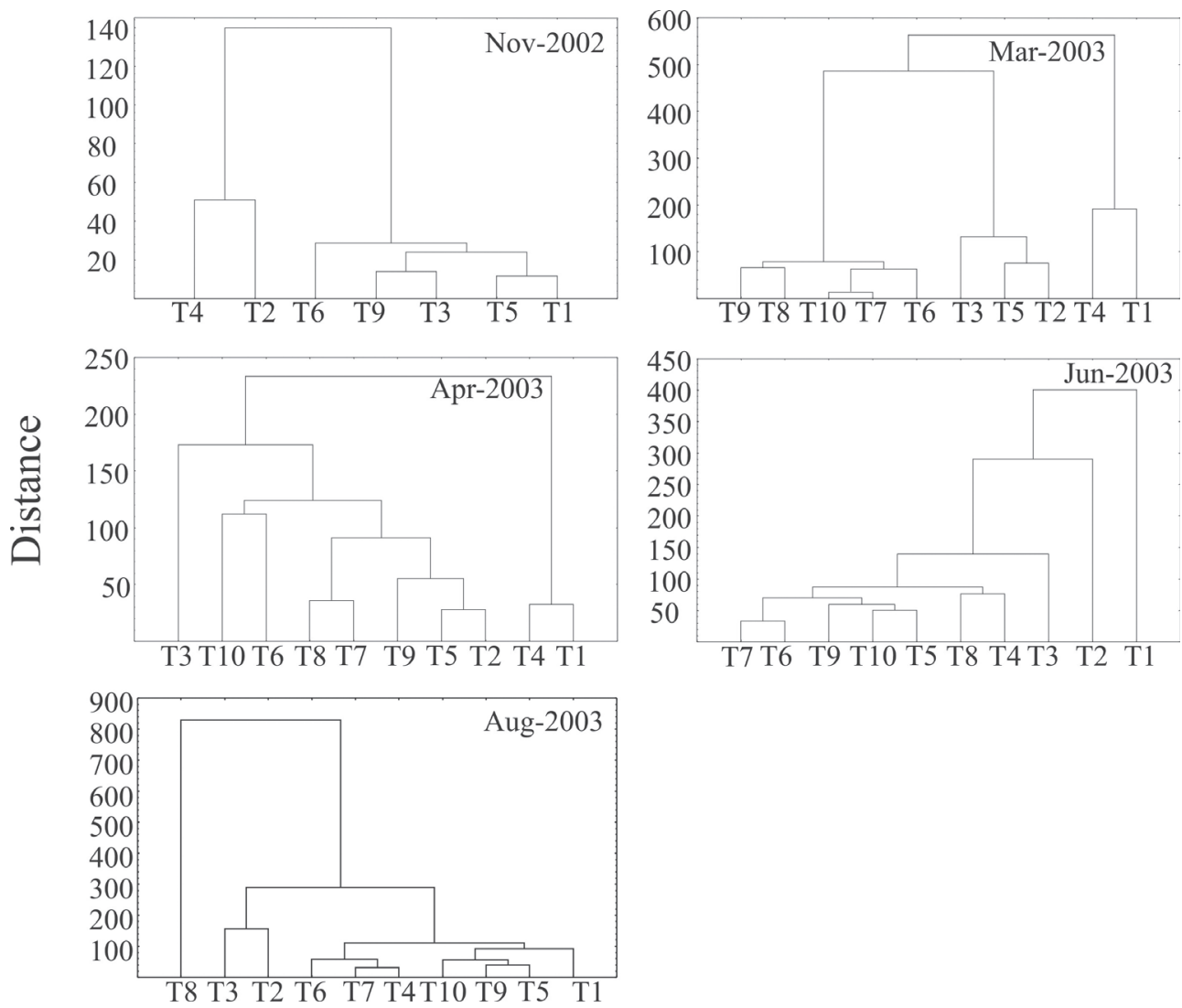

Fig. 5: Dendogram of affinity for transect in relation to the density of the species for months. Dendograma de afinidad de transectos en relación a la abundancia de las especies por mes. 

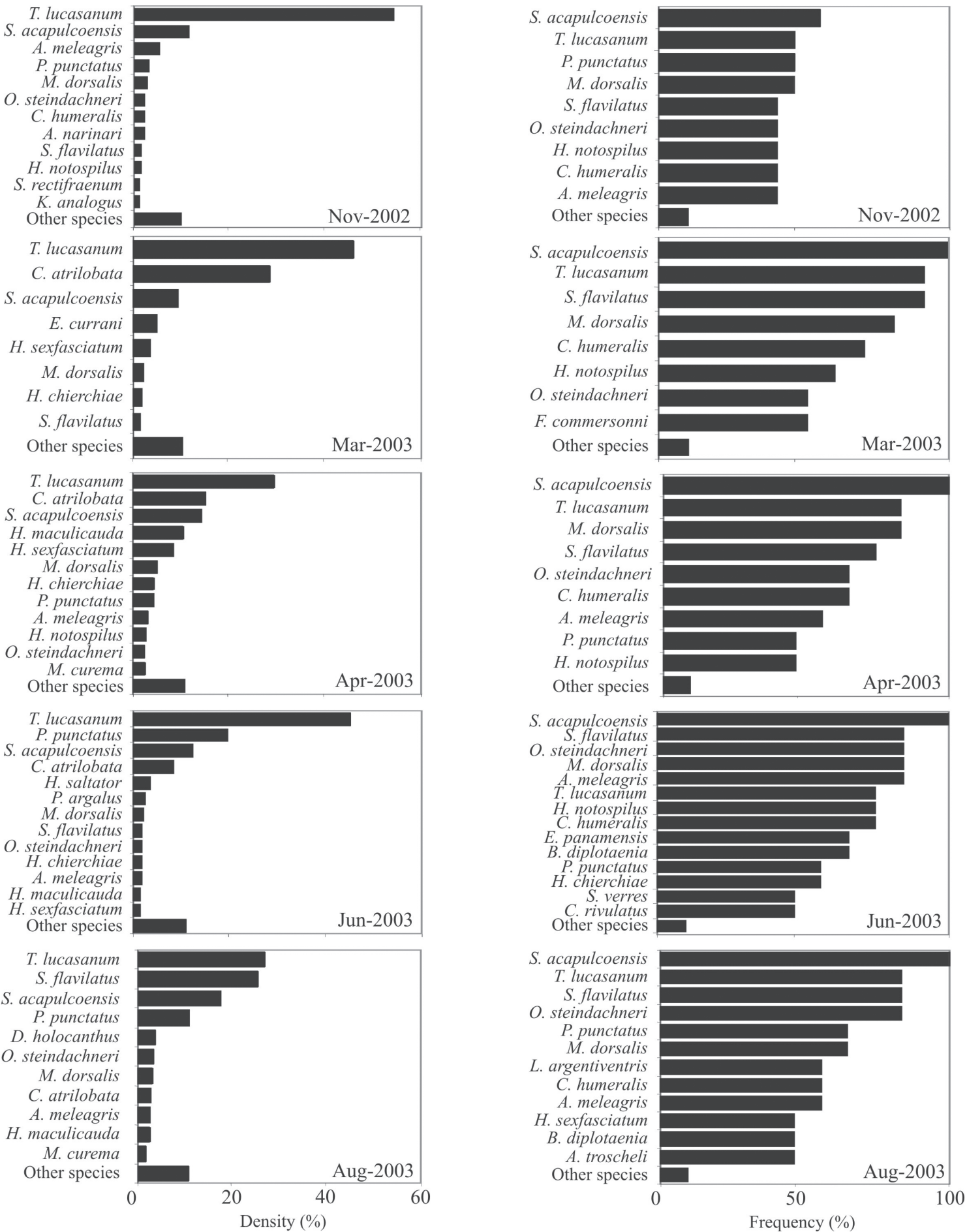

Fig. 6: Relative density (\%) and frequency (\%) of the species for months.

Densidad relativa (\%) y frecuencia (\%) de las especies por mes. 
TABLE 2

Student t-tests (P-value) among different habitats in San Agustín bay

Pruebas t de Student (valor de P) entre hábitat de la bahía de San Agustín

\begin{tabular}{lccccc}
\hline Habitat & November 2002 & March 2003 & April 2003 & June 2002 & August 2002 \\
\hline Coral rubble versus coral reef & $-2.15(0.684)$ & $-1.41(0.188)$ & $-1.84(0.0805)$ & $-2.00(0.0658)$ & $-1.15(0.1638)$ \\
Coral reef versus rocky reef & $2.62(0.0204)$ & $2.26(0.0408)$ & $3.40(0.0033)$ & $3.37(0.0046)$ & $2.61(0.0202)$ \\
Coral rubble versus rocky reef & $-0.29(0.7759)$ & $0.22(0.830)$ & $1.69(0.1131)$ & $2.11(0.0614)$ & $1.38(0.1994)$ \\
\hline
\end{tabular}

\section{DISCUSSION}

With relation to the fish community density of San Agustin bay, the higher fish densities occur in June and August, corresponding to the rainy season, in coral rubble and coral reef environments, and the lower densities occur in November, March and April, corresponding to the dry season, mainly in rocky reef environment (Fig. 2 and 3). The high density was determined mainly by $C h$. atrilobata, $M$. dorsalis, P. punctatus, S. acapulcoensis, S. flavilatus, and T. lucasanum. When species like Caranx caninus (Günther, 1869), Sardinops caeruleus (Girard, 1854), and Selar crumenophthalmus (Bloch, 1793) constituted great shoals; the visual censuses of these species were not used to do estimations of density and diversity, because this information could not be reliable and determine possible biases in the estimation of the diversity and density. In addition these species are occasional or cyclical and do not comprise the group of resident species of the community. However, as a result of the high density of these species and their ecological importance as cyclical or occasional species, the density data are included.

In the three environments (coral rubble, coral and rocky reef) there was not an important variation in the space distribution of the species. This can be due to that the three environments present an important environmental heterogeneity, with the exception of the plain of the coral reef, whose topography is less complex, but of greater dimensions than the other environments. The higher values of diversity ( $H^{\prime}$ ) were in June and August (rainy season) in coral and rocky reefs environments, probably as a result of the high temperature values and the high production of the regional coastal processes (Lluch-Cota et al. 1997, Lara-Lara et al. 1998), and the low density of gregarious species like C. canninus, and $S$. crumenphthalmus which are active predators (Allen \& Robertson 1994).

In November the differences between environments were not significant (Student ttest) and the values of diversity were the lowest. These results can be due to November is the beginning of the dry season, then the coastal production processes diminish, and the gregarious predators species, mainly $S$. crumenophthalmus, are abundant. The changes of the fish community structure are closely related to temperature variation and the changes of the most abundant species within the system. Like the diversity (H'), the species richness (D') has the same pattern. However, the equitability (J') was higher in November on areas of coral reef and coral rubble where the deep is lesser than $2 \mathrm{~m}$, inclusive the coral reef could be exposed when the tide is low, which disables the incursions of gregarious predators fish.

With relation to the environments, the higher diversity and species richness on rocky reef and coral rubble is because these subsystems have more heterogeneity than the coral reef, mainly where the plain is, which provides topographic complexity of the system and therefore availability of refuge and habitat for the species. For the rocky and coral reefs the most frequent species were the Pomacentrids, like M. dorsalis, $S$. acapulcoensis, and S. flavilatus. In the area of coral rubble the most frequent was the family Labridae, with the species Halichoeres chierchiae (Caporiacco, 1947), H. dispilus (Günther, 1864), and H. notospilus (Günther, 1864), and the family Haemulidae with Haemulon maculicauda (Gill, 1863). The areas with scarce environmental heterogeneity, as the coral reef plain, limit the refuge availability, and 
then the dominant species were Ch. atrilobata, $S$. acapulcoensis, and T. lucasanum. The diversity of the reef fish community depends on the complexity of the construction of the reef, reason why the coral reef plain has less availability of microhabitats and refuge, diminishing the diversity of this environment with relation to the rocky reef and coral rubble environments (Hobson 1974, Hatcher 1981, Syms \& Jones 2000, Almany 2004).

As a result of the high density and frequency throughout the year, Ch. atrilobata, $M$. dorsalis, $P$. punctatus, $S$. acapulcoensis, and $T$. lucasanum, were dominant. Other species like $C$. caninus, $S$. caeruleus, and $S$. crumenophthalmus, presented high density, but low frequency, because these species are cyclical or occasional visitors of the study area. According to Allen \& Robertson (1996) $C$. caninus, $S$. caeruleus, and $S$. crumenophthalmus have not been reported in coral reefs; nevertheless in this study are frequent species. The presence of these species could be related to seasonal factors, as the upwelling of the central part of the Gulf of Tehuantepec, from November to May (Monreal \& Salas 1998), where the cold water is moved by local currents into the west where the Huatulco bays are. This water is rich in nutrients that determine a high primary productivity of the system, which has an effect on the food availability for the species; although at the same time the low temperature is a limiting factor. Also, these species can have direct influence on the recruitment, competition (Robertson 1996), and/or depredation (Hyxon \& Beets 1993), altering the stability of the fish community. This is related to the lowest diversity with the presence of these species the lowest values of diversity and richness were obtained, probably due to an intense depredation on the resident fish, and competition by the resources.

The herbivore species like $S$. acapulcoensis, $M$. dorsalis, and $P$. punctatus, as a group, represents an important pathway in the maintenance of coral reefs and the life that they support, because these species are the main exporters of the primary productivity towards superior food levels. Also, the effects of these species on the seaweed communities are fundamental in the reef ecosystem stability (Carpenter 1986, Hyxon \& Brostoff 1996).
With relation to the resident gregarious fish species, in the case of $C h$. atrilobata, $P$. punctatus, and T. lucasanum, three of the five dominant species for this system, they can have implications on the coral reef fish species distribution. For example the presence of conspecific individuals can be an indicator of the quality of the habitat for the colonization by larvae (Levin 1993). The growth and survival larvae can be increased when the colonization by conspecific adults occurs, if the resources are not limited; however, when the intraspecific competition increases with the adults or other recruits can reduce to the growth or survival of individuals of the same species that colonize the system (Forrester 1990).

With relation to the diversity and species richness values, these have an inverse relation with the presence of cyclical or occasional species of great shoals, like $C$. caninus, $S$. caeruleus, and $S$. crumenophthalmus. During the months where the low diversity values were registered (November and March), the density of these three species was high. It is probable that the presence of these species is associated to the upwelling of the Gulf of Tehuantepec during the dry season (October-April) (Monreal \& Salas 1998), which determines adequate water temperature and food availability for these species, but not adequate environmental characteristics for the "tropical" coral reef fishes.

The coral reef fauna of the Huatulco bays is poor, in comparison with other coral reef systems, like those of the Caribbean Sea and Western Indo-Pacific. These great differences have been explained in a regional biogeography context (Briggs 1964), where, although the East Pacific region has a large geological and ecological history, also it has a scarce continental shelf and a low environmental heterogeneity, which diminishes the area and substrate availability for the colonization of the coralline colonies. Another important factor is the influence of the upwelling wind driven presented in mid part of the Gulf of Tehuantepec (Monreal \& Salas 1998), which pushes cold water into the Huatulco bays and determines environmental conditions not adequate for the establishment and development of the coral reef species. The Gulf of Tehuantepec processes exert great effect on the community dynamics of the Huatulco bays, mainly on the tropical coral reef systems. 


\section{ACKNOWLEDGEMENTS}

This work derives of the research projects supported by the Universidad Autónoma Metropolitana-Iztapalapa and the Parque Nacional Huatulco, thanks to the authorities, mainly to Silvia Niembro Rocas. We appreciate the revision and suggestions to this work by Antonio Valencia Hernandez. We thank Jose Luis Moreno, Ricardo Campos, Rocío Gomez, Jacqueline Flores and Cristal Ayala for their help and cooperation during the fieldwork.

\section{LITERATURE CITED}

ALLEN GR \& DR ROBERTSON (1994) Peces del Pacífico oriental tropical. CONABIO. Agrupación Sierra Madre y CEMEX, Hong Kong, China. 327 pp.

ALMANY GR (2004) Does increased habitat complexity reduce predation and competition in coral reef fish assemblages? Oikos 106: 275-284

BARRIENTOS-VILLALOBOS J (2000) Diversidad y abundancia de la ictiofauna de los arrecifes coralinos del Parque Nacional Huatulco. Tesis profesional de licenciatura en biología, Universidad Autónoma de Puebla, Puebla, México. 52 pp.

BRIGGS JC (1964) Additional transpacific shore fishes. Copeia 4: 706-708.

CARPENTER RC (1986) Partitioning herbivore and its effects on coral reef algal communities. Ecological Monographs 56: 345-363.

FISCHER J, W KRUPP, F SCHNEIDER, W SOOMER, C CARPENTER \& VH NIEM (1995) Guía para la identificación de especies para los fines de la pesca. Pacífico centro-oriental. FAO, Rome, Italy.

FORRESTER GE (1990) Factors influencing the juvenile demography of a coral reef fish population. Ecology 71: 1666-1681.

HATCHER BG (1981) The interaction between grazing organism and the epilithic algal community of coral reef; a quantitative assessment: 515-524. In: Gómez E, C Birkeland, R Buddemeier, R Johannes, J Marsh \& R Tsuda (eds) Fourth international coral reef symposium. Manila, Quezon, Philipines.

HOBSON ES (1974) Diel feeding migration in tropical reef fishes. Helgoländer Wissensch Meersunters 2: 361-370.

HYXON MA \& JP BEETS (1993) Predation, prey refuge, and the structure of coral reef fish assemblage. Ecological Monographs 63: 77-101.

HYXON MA \& WN BROSTOFF (1996) Succession and hebivory: effects of differential grazing on Hawaiian coral-reef algae. Ecological Monographs 66: 67-90.

LARA-LARA JR, EG ROBLES-JARERO, MC BAZÁNGUZMÁN \& E MILLÁN-NÚÑ̃E (1998) Productividad del fitoplancton. El Golfo de Tehuantepec: el ecosistema y sus recursos. Universidad Autónoma Metropolitana-Iztapalapa, Distrito Federal, México. 239 pp.
LEVIN GP (1993) Habitat structure, conspecifics presence and spatial variation on the recruitment of a temperate fish. Oecologia 94: 176-185.

LEYTE-MORALES GE (2001) Estructura de la comunidad de corales y características geomorfológicas de los arrecifes coralinos de Bahías de Huatulco, Oaxaca, México. Tesis de Maestría. Instituto de Recursos de la Universidad del Mar, Oaxaca, México. 94 pp.

LIESKE E \& R MYERS (1998) Peces de arrecifes coralinos del Indo-Pacífico y Caribe. Omega, Barcelona, España. 399 pp.

LLUCH-COTA SE, S ÁLVAREZ-BORREGO, EM SANTAMARÍA-DEL ÁNGEL, FE MULLERKARGER \& S HERNÁNDEZ-VÁSQUEZ (1997) El Golfo de Tehuantepec y áreas adyacentes: variación espacio-temporal de pigmentos fotosintéticos derivados de satélite. Ciencias Marinas 23: 329-340.

MARGALEF R (1968) Perspectives in ecological theory. University of Chicago, Chicago, Illinois, USA. 240 pp.

MONREAL-GÓMEZ MA \& DA SALAS de LEÓN (1998) Dinámica y estructura termohalina. El Golfo de Tehuantepec: el ecosistema y sus recursos. Universidad Autónoma Metropolitana-Iztapalapa, Distrito Federal, México. 239 pp.

NELSON JS (1994) Fishes of the World. Wiley \& Sons, New York, New York, USA. 600 pp.

PIELOU EC (1977) Mathemathical ecology. Wiley \& Sons, New York, Nueva York, USA. 365 pp.

PIELOU EC (1984) The interpretation of ecological data. A primer on classification and ordination. Wiley \& Sons, New York, NuevaYork, USA. 145 pp.

REYES-BONILA \& GE LEYTE-MORALES (1998) Corals and coral reefs of the Puerto Angel region, west cost of México. Revista de Biología Tropical 46: 679-681.

ROBERTSON DR (1996) Interspecific competition controls density and habitat of territorial Caribbean damselfishes. Ecology 77: 885-889.

SALE FP (1980) The ecology of fishes coral reef Oceanography and Marine Biology an Annual Review 18: 367-421

SALE FP \& WA DOUGLAS (1981) Precision and accuracy of visual census technique for fish assemblage of coral patch reef. Environmental Biology of Fishes 6: 333-339.

SHANNON CE \& W WIENER (1963) The mathematical theory of communication. University of Illinois, Chicago, Illinois, USA. 173 pp.

SOROKIN I (1995) Coral reef ecology. Springer, New York, New York, USA. 465 pp.

SYMS C \& JP JONES (2000) Disturbance, habitat structure, and the dynamics of a coral-reef fish community. Ecology 81: 2714-2729.

SOSA-ROSAS L (1995) Composición y variación del zooplancton presente en algunas localidades del desarrollo turístico Bahías de Huatulco, Oaxaca, durante 1990-1991. Tesis de Maestría en Ciencias, Facultad de Ciencias, Universidad Nacional Autónoma de México, Distrito Federal, México. 94 pp.

WARD J (1963) Hierarchical grouping to optimize an objective function. Journal of the American Statistical Association 58: 236-244.

ZAR JH (1984) Bioestadistical analysis. Prentice-Hall, Englewood-Cliffs, New Jersey, USA. 718 pp. 